\title{
The confessing academic and living the present otherwise: Appraisal interviews and logbooks in academia
}

\author{
Andreas Fejes \\ Linköping University Post Print
}

Tweet

N.B.: When citing this work, cite the original article.

Original Publication:

Andreas Fejes, The confessing academic and living the present otherwise: Appraisal interviews and logbooks in academia, 2016, European Educational Research Journal (online). http://dx.doi.org/10.1177/1474904116636637

Copyright: SAGE Publications (UK and US)

http://www.uk.sagepub.com/home.nav

Postprint available at: Linköping University Electronic Press

http://urn.kb.se/resolve?urn=urn:nbn:se:liu:diva-125363 


\title{
The confessing academic and living the present otherwise: appraisal interviews and logbooks in academia
}

Andreas Fejes, Linköping University, Sweden

andreas.fejes@liu.se

Fejes, A. (2016) The confessing academic and living the present otherwise: Appraisal interviews and logbook in academia. European Educational Research Journal. DOI: $10.1177 / 1474904116636637$.

\begin{abstract}
In this paper, drawing on the work of Michel Foucault, I argue that academics are enmeshed in power relations in which confession operates, both on and through academics. Drawing on Foucault's genealogy of confession, I illustrate how academics are not only invited to reflect on performance, faults, temptations and desires in their work and private life, but as teachers they mobilise the same kind of technology in relation to students. These power relations are connected to wider changes in society, where discourses on New Public Management have become all pervasive in organising and governing public institutions. The examples of the use of appraisal interviews and logbooks as governing techniques illustrate how government currently operates through the freedom of the individual. The paper ends with a discussion on how books of life could introduce a different relation of the self to the self in academia, and thus provide opportunities to live the present otherwise.
\end{abstract}

\section{Keywords: Confession, Academia, Higher Education, Foucault, Appraisal interviews, Logbooks}

\section{Introduction}

Today, we are witnessing major changes in academia within a framework of a neoliberal discourse on how to govern and shape the university, university managers, teachers and students. New Public Management (NPM) is infiltrating academic life at all levels (cf. Schimank, 2005; Deem, 2004), externally as well as internally, providing a new language and new techniques for governing. Through goal-oriented governance, universities in Europe and beyond, are asked to deliver research and teaching of "high quality", but are left to decide themselves how to best deliver such "quality". An "audit society" (Power, 1997) emerges, where techniques are deployed externally as well as internally to assess if universities, departments, research groups and individual academics deliver the quality asked for. Techniques deployed for measurement and comparison often draw on quantified data, where things that might not be possible to quantify, are quantified, constructing what Liedman (2013) calls pseudo-quantities. Even though such techniques can be seen as possible ways to construct quality, these techniques do something to the subjectivities of academics. We have what Nikolas Rose (1991) call a governing by numbers, through which academics are enmeshed in power relations and in different ways engaged in governing themselves and others (Fejes and Nicoll, 2015).

Governing by numbers operates, for example, through current systems for distributing research funding, e.g. in the UK and Sweden (se www.ref.ac.uk, and Ministry of Education, 2007) where quantitative measures are used for determining excellence in research, such as the number of papers researchers publish in certain kinds of format (articles) in a particular language (English being the most important), the extent to which they publish in certain journals (those indexed in databases such as the web of science) and how often articles published in these journals are cited (see Fejes and Nylander, 2014; Larsson, 2009a, 2010). 
Such numbers are also used within universities by rectors and managers when ranking departments and individual scholars, and they affect the way academics behave in terms of what, where and how to publish (Fejes and Nylander, 2014). Governing also operates internally through a range of practices such as the appraisal interview (cf. Krejsler, 2007), student's evaluation of teachers, teacher's use of different pedagogical techniques (cf. Fejes, 2011) as well as in their assessment of students (cf. Nicoll, 2015). These tools provide possibilities to engage academics as well as students in a process of constant assessment, evaluation and comparison. Everyone is thus positioned as both a person who is being assessed and evaluated, as well as a person who is carrying out such an assessment of him/herself and of others. In other words, governing here becomes what Foucault (2007) called "the conduct of conduct".

The operation of governing through the conduct of conduct has been elaborated upon by a range of scholars in the field of education (e.g. Simons et al, 2008; Peter et al., 2009, Fejes and Nicoll, 2008). A main focus of such research has been on the ways the individual turns herself into a subject through different technologies of the self. During recent years, the confession has become one such technology under scrutiny (e.g. Besley and Peters, 2007; Zembylas and Fendler, 2007; Fejes and Dahlstedt, 2014; Fejes and Nicoll, 2015). Confession is argued to be important, e.g. in the self-shaping work of pupils in school through cognitive behavioural therapeutic programs (Dahlstedt et al, 2011), through current discourses on emotion (Zembylas and Fendler, 2007), through grading (Breidenstein and Thomson, 2015), through the shaping of teachers within teacher education (Popkewitz and Kirchgasler, 2015), and through the use of pedagogical techniques in in-service training programs (Fejes, 2011). In relation to academia, Olson et al. (2015) illustrate how national systems of higher education are standardised through confessional logics operating in policies of the EU. The academic is in focus in Hodgson's (2015) analysis of devices for the self-monitoring of academics and their performance, and in Nicolls' (2015) analysis of academics' assessment of students. Here, confession becomes a tool for a critical investigation into how power operates within academia today, and provides an opportunity to question the taken-for-granted-ness of current changes.

In this article, drawing on the work of Foucault $(1998,2007)$ and the notions of confession, conduct of conduct, technologies of power and the self, the aim is to provide a critical analysis of some contemporary changes within academia. I shall argue that current discourses on how academia and the academic are governed are "dangerous" (cf. Foucault, 1983), or rather, that these discourses represent one of the main dangers in academia today, as they "do" something to who we "are". Through engaging in an analysis of how confession is mobilised through two specific governing techniques, the appraisal interview and the logbook, I will illustrate how the academic is positioned as both the one who confesses and the one who demands the confession of others. The aim of such analysis is to destabilise the current "reality" of the university, involving who academics are and who they should be. This is not intended to "lead to apathy but to a hyper- and pessimistic activism" (Foucault, 1983: 231-232) where the choice of approach and research interest is an "ethico-political choice" (Foucault, 1983: 231-232) which might provide opportunities for living the present otherwise (Foucault, 1979).

\section{Conduct of conduct governing the academic}

To focus on the conduct of conduct and the technology of confession is to focus on relationships of power. Here, power is not something that people have, own and use on others. Rather, power is here seen as relational. Instead of asking the "what" question of power, the 
question rather becomes the "how" of power (Foucault, 1983). How does it operate and with what effects? This is a dual question about power and governing. A "how" question of governing becomes one of technologies of power (of a domination that is both productive and limiting) and technologies of the self. The first concerns the practices through which a self is objectified - made an object for examination and regulation and construed as normal or abnormal in order that it can be corrected. The latter concerns the way the self shapes itself into a new and improved form. Technologies of power and of the self do not function separately. Rather, the encounter between the two is what Foucault called government (Foucault, 2007).

Technologies of power and of the self operate in academia today, and through these, subjectivities of academics and students are shaped and fostered. The performance of academics is evaluated through a range of practices where power operates, inviting and requiring the academics to turn their gaze inwards, scrutinising who they are, their character, their faults, their limitations, their ambitions, desires and their goals in life, and then disclosing these to their manager and their students. They are also encouraged to see themselves in terms of the "virtual other", when it comes to the norms of good academic behaviour (cf. Foucault, 1998; Fejes and Dahlstedt, 2014). Academics are not only invited to confess, they are also encouraged to invite others to confess to them in their role as teachers and to confess to "virtual others" (Foucault, 1998). This could be in teaching sessions, through the use of assessment tools such as the portfolio, or through other reflective instruments where students are asked to assess their own performance. This means that academics are engaged in governing and shaping themselves and others.

It is therefore a question of government, both of themselves and of others: "For to 'conduct' is at the same time to 'lead' others (according to mechanisms of coercion which are, to varying degrees, strict) and a way of behaving within a more or less open field of possibilities" (Foucault, 1983: 220-221). Here, the "autonomous" academic and individual as a subject is shaped to make his or her own choices and decisions in terms of how this is "desired" by governing practices. Today, the subject of autonomy is both the prerequisite for and the effect of government (in terms of the conduct of conduct). Because societies seek autonomy as a form of prescribed freedom for their people, practices of government become acceptable and can be used productively. It is through the conduct of conduct that people come to govern themselves as well as others. Government is therefore a much broader concept than governing of the state. It involves governing of the self and of others, as well as the government of the state (Foucault, 2007).

Through the confession, academics therefore govern themselves as well as others, and this argument will be developed in this article. Firstly by elaborating on Foucault's genealogy of confession, and secondly by analysing how such technology operates in academia today through the governing techniques of the appraisal interview and the logbook. These techniques are chosen as they are commonly used in higher education today involving the academic, as well as being mobilised in practices in which the academic is positioned differently in terms of power. In the appraisal interview, the academic is positioned in relation to a manager, while in the use of logbooks the academic is positioned in relation to students. It is thus possible to see how confession operates through different subject positions made available to the academic.

In analysing how the confession operates, I draw on the work of Michel Foucault (1983, 1998, 2007) and scholars who have been elaborating on his idea more philosophically 
(Taylor, 2010) as well as more directed at education (Fejes and Dahlstedt, 2014; Fejes and Nicoll, 2015) directing my interest at regularities of statements in descriptions about the appraisal interview and logbooks. The focus is thus on what discourse makes possible in terms of confession, rather than on reality par se. Texts were collected that could provide a basis for such analysis. The appraisal interviews are mobilised by the universities, and thus policies on such interviews from two universities in Sweden were collected for further analysis. The two universities, the University of Gothenburg and Malmö university, represent two different categories of universities in Sweden, the former an older one and the second a regional one (högskola). Thus, illustrating how the appraisal interview as technique is not only limited to one of the other of these kinds of institutions. Logbooks on the other hand are mobilised by academics in their teaching, and thus their own texts on how they use and wish to use logbooks were collected from research journals. Here, I used databases such as scholar Google and ERIC searching for the keywords logbooks and higher education. The aim was to collect articles by authors from different countries as well as from different scientific areas, thus being able to illustrate how the confession has spread across higher education geographically and discipline wise. Thus, the aim is to provide the possibility for what Larsson (2009b) call "generalisability through context similarity", where the reader might be able to see similarities to their own practice in relation to the argument presented here.

\section{A genealogy of confession}

Today's confessional practices are not a unity or a homogeneity, nor are they immutable. My purpose here is to provide a short genealogy, a historical account of lines of descent and emergence of confessional practices, in order to begin to problematise these as they operate today in academia, so that they can then be looked on anew and assessed critically. Foucault's wider historical analysis of technologies of the self at different periods in the "West" aimed to demonstrate this. His analysis was not intended to construct a history of these forms, for this would be an attempt to contribute to the analysis of history as progression. Nor is my argument intended in this way. Foucault suggested that techniques of confession, which focus specifically on "verbalisation" of the self, emerged as practices of the human sciences. He argued that knowledge acquisition in the human sciences required this technique, so these practices and this knowledge supported the establishment of a new way of governing (Foucault, 2003). In contemporary times, therefore, confession has become "scientised" "through clinical codifications, personal examinations, histological techniques, the general documentation and data collection of personal data, the proliferation of interpretative schemas and the development of a whole host of therapeutic techniques for "normalization" (Besley and Peters, 2007: 16). Verbalisation has become linked to science, and reinvented in practices which promise to help us live a better life. This "scientisation" places confession in the interface between public and private domains, where it always requires an "other", either real or virtual, to whom one confesses (cf. Fejes and Dahlstedt, 2014; Foucault, 1998; Rose, 1989).

In his genealogy, Foucault traced the confession back to the Ancient Greeks, and the relationship between the Greek practices of "care of the self" and the Delphic statement "know yourself”. During the Greco-Roman period, the latter (knowing yourself) appeared as a consequence of the former (care of the self), where much later, the Christian concept of knowing yourself obscured "care of the self". Self-renunciation in Christianity came to be a condition for salvation. In order to renounce the self, you had to know yourself. Foucault elaborated on how the relationship between care of the self and knowledge of the self emerged and changed during the Greco-Roman period, in contrast to practices influenced by 
the emergence of Christianity and the present era, which have produced different forms with distinguishable effects in terms of power relations.

During the Greco-Roman period, care of the self was a general philosophical principle. To care for the self was to make life an art object - a "tekhne". To care for the self was about existence. Care of the soul was an art, but only in so far as it involved caring for the activity of the soul and not the soul as a substance. The aim was to develop good values in life (as opposed to values aimed at a life after death, as occurred later in Christianity). Writing became an important technique in this endeavour. Taking notes about oneself and the activities of the day, reviewing them and keeping notebooks, was a way "to reactivate for oneself the truths one needed" (Foucault, 2003: 153). Through this writing, the subject became the object of the writing activity. Writing was not about knowing oneself and searching for the truth about oneself as would later be the case in Christianity. Instead, writing was about finding the truths an individual needed in order to develop good values and turn life into the art of existence.

Examination of conscience emerged within this writing activity as a technique of the GrecoRoman period. For the Stoics, this involved a self-examination of the deeds of the day. However, the writer was not looking for bad intentions. Faults were simply good intentions left undone. The focus was on remembering the truth or recovering a truth that had been forgotten, in order to be successful in one's intentions and to develop good values in life. The subject had not forgotten himself, but had forgotten the rules of conduct and what ought to have been done. By recalling errors committed, the subject emerged in the gap between what had been done and the rules for what should have been done: "The subject constitutes the intersection between acts that have to be regulated and rules for what ought to be done" (Foucault, 2003: 157). Thus, self-regulation became important in the art of living, where the focus was on the activities and deeds of the person rather than on the thoughts. Care of the self as a writing activity and an art of the self also constituted knowledge of the self in relation to these rules of conduct. As I will illustrate later, this focus is different from Christian concepts where the focus was on thoughts, verbalising and making sins visible.

Another stoical technique for the care of the self was known as askesis. Askesis involved drawing truth out from memory, "not a disclosure of the secret self but a remembering" (Foucault, 2003: 158). The truth was once more not to be found within the self, but in the teachings of the master. The master's words were memorised and turned into rules of conduct. The aim was to make life subjective through truth and to prepare for the reality of the world (Foucault, 2003: 158). Askesis involved remembering the truth of the master as a set of rules for shaping self-care on a daily basis. The Stoics thus construed care of the self as an activity that required listening and remembering rules. These activities were methods of preparing for life as an art, and ways of mastering the self. The techniques of writing, self-examination and askesis were integral methods of caring for the self, through which individuals trained themselves for life.

With the emergence of Christianity in the third and fourth centuries, the relationship between care of the self and knowledge of the self was reconfigured. Aesthetics were no longer concerned with existence, but became linked to purity. The aim of caring for the self was to maintain purity. Physical integrity rather than self-regulation became important. The self was no longer something to be created (an art of living), but rather something to be renounced and deciphered. Care of the self was replaced by a requirement to know the self in terms of personal sins. In Christianity, writing became a test that "brings into light the movements of 
thought, it dissipates the inner shadow where the enemy's plots are woven” (Foucault, 1983: 248). In Christianity, writing was used to help individuals find the truth about themselves as a way of accessing the light, by making their inner thoughts visible to themselves (disclosing themselves). To renounce oneself one had to know oneself, and this truth was deciphered through writing. Knowing oneself, renouncing the self and one's sins through writing as a form of purification, became the way to truth.

The technique of writing, as well as associated techniques of disclosure and renunciation, was at the time of the emergence of Christianity, directed at a few selected. However, with the emergence of the Catholic Church, confession, and its associated techniques, spread further beyond the realms of a selected few, and took new forms. At the beginning, the penitents kneeled before the feet of the priest, who knew the sinner and could remember previous confessions and in the $16^{\text {th }}$ Century, the confessional box was introduced in which the confession would take place. The sinner needed to show remorse and accept the status as a sinner, in order to receive absolution. Confession within the Catholic Church came to be obligatory. (Taylor, 2010) With the emergence of the human sciences in the $17^{\text {th }}$ and $18^{\text {th }}$ Century, confession was once again reshaped. The focus shifted to knowledge of the self and verbalising this knowledge without renouncing the self. As Foucault (1998) illustrated how, as a result of a will to know the truth about sexuality, a secularised discourses took hold in which the aim came to be an "internalization of the coercion to confess, that it is today experienced as a pleasure and a desire" (Taylor, 2010: 67). Rather than a renunciation of the self, the focus came to be on building a new and improved self. With this, a different type of rationality of governing emerged, aiming to shape and foster subjects, simultaneously governing themselves and others through the conduct of conduct (Foucault, 2007).

\section{Confession in academia today}

The genealogy of confession presented serves as a background in order to understand and elaborate on how confession operates in the present, and thus, what possibilities there might be to live the present otherwise. In order to problematize the way academia and the academic are governed today, I will now focus on the ways confession operates through the appraisal interview and the logbook. The level of analysis is on regularities of statements, i.e. on how a discourse on confession is shaped and operates through the material analysed. My focus is thus on what discourse makes possible in terms of confession, rather than on reality par se.

\section{Appraisal interviews}

As I have noted above, more and more measurements are being introduced to assess the quality of researchers' performance, such as bibliometric analyses and student assessment of a teacher's performance. The appraisal interview is yet another such technique, similar to those used in the public as well as the private sector. This type of appraisal is not in itself a new practice. However, it is one which has changed during the last decade (cf. Deem, 2004; Krejlser, 2007), e.g. in universities in Sweden. These interviews focus on discussing the progress of the employee in relation to the "needs" of the university, and they are often framed as a relationship between equals, indicated by their Swedish name: medarbetarsamtal (directly translated into English as conversation between co-workers, showing that the manager and the employee are construed as having a horizontal rather than vertical relationship). This type of terminology was introduced for the appraisal interview a couple of decades ago. Previously these interviews were, and in some locations still are, called utvecklingssamtal (directly translated into English as developmental conversation, indicating that they involve the personal development of an individual). The shift in terminology for the appraisal interview indicates new power relations and the shaping of a different kind of 
subjectivity. In the first instance, it might seem as if these interviews have become more "equal". However, if we look more closely at how the interviews are described we can see how they are expressions of other forms of power-relationships and government.

Let us turn to some of the guidelines for appraisal interviews at two Swedish universities, Malmö University and the University of Gothenburg, in order to see how they shape academics. At Malmö University (p. 2) the stated aim of the appraisal interview (medarbetarsamtal) is that:

Each employee should be given the opportunity to influence her/his work and her/his own work conditions, as well as the prerequisites for this. The appraisal interview should be a forum where manager and co-worker engage in dialogue to plan, develop and follow up the work of the employee. This includes participation in developmental work and activities for developing a work environment with equal treatment, which helps to create a healthy environment in the workplace. The dialogue between manager and co-worker should be conducted so that each party can express her/his opinions during both daily activity and at the regular appraisal interview between manager and co-worker. There should be at least one interview of this type each year. The interview should be planned, prepared and structured.

The above quotation introduces the complexity of the discourse emerging and how both technologies of power and the self are at play. On the one hand, the appraisal interviews', and their reoccurrence each year, is decided by the employer, and the manager is assigned the task of carrying them out. Thus, the manager is construed as someone who is in a position of power. He/she invites the employee to reflect and speak about how work conditions and results can be improved, at the same time as the manager is providing feedback on the achievements and actions of the employee. The employee thus knows that s/he is being monitored by the manager, which is not only limited to the interview, as this should be a continuous process during "daily activity". On the other hand, the relationship between manager and employee is shaped as horizontal, rather than vertical. Statements such as "dialogue" and "co-worker" invite and encourage employees to disclose their thoughts on work practice, their own achievements, as well as the achievements of the manager. A space is thus shaped in which power relations provide possibilities for manager and employee to engage in a "truth" game where the employee is being shaped by the manager as well as by her/himself.

We can see similar reasoning in the guidelines from the University of Gothenburg, which calls its appraisal interviews utvecklingssamtal (p. 1):

Below you will find some important themes for reflection before the interview. View these as suggestions about how to prepare yourself, rather than as a checklist for the interview. The interview is intended to benefit both you and your manager, and it is a tool for coordinating and developing work practice. Your manager has prepared questions she or he wishes to raise, and both of you are jointly responsible for ensuring the interview is constructive.

Here we can see that, even though the appraisal interview is termed utvecklingssamtal, the relationship between co-worker and manager is construed as horizontal through statements such as "the interview is intended to benefit both parties" as well as "you are jointly 
responsible". Furthermore, the employee is invited to reflect on questions before the interview, such as, "Are any outside factors influencing your work?", "How do you wish to develop your work in future?", "What are your long-term goals?”, "How well do your goals relate to the goals and profile of the university?", "In what ways could you influence the fulfilment of your goals?”, "What support would you need?"

The above quotations further illustrate the intersection of technologies of power and the self and how, through these, academics are being shaped, governed, and govern themselves in specific ways. Firstly, these technologies are here related to questions of epistemology. The focus of the interview is partly on stating "facts" about what has been done, the output of these actions, and a discussion about how things can be done in the future, i.e. how practice can be improved. In this case, academics are assessed both by their managers and by themselves on the quality of past actions, rather than on the quality of the "inner self". Through the employee knowing that there is always potential monitoring of their behaviour by the manager, disciplinary power operates in order for the employee to behave and act according to norms of good behaviour. The aim is to shape employees who participate "in developmental work and activities”, and through such work, a responsible and self-shaping subjectivity should emerge.

Secondly, the technologies relate to questions of ontology, about changing the inner self. By asking academics to participate in creating a "healthy environment", asking them if there are "any outside factors influencing work", what their goals are, how these can be fulfilled and what support they would need to fulfill them, the focus is not only on reflecting and improving practice as well as the actions of the academic, but also on improving the self. By asking these questions, the employees are asked to scrutinize their inner selves, i.e. turn their gaze towards who they "truly are" and who they wish to become. Such reflections should be disclosed to the manager through which an ideal subjectivity is being shaped and fostered. However, confession as technology of the self here intersects with technologies of power. Through the act of disclosure, the feedback provided by the manager, and the potential support decided upon, the employee is objectivised and shaped in relation to the norm of a good academic. The goals of the operation of these technologies are, on the one hand, to shape the academic within the framework of the goals and strategies of the university, and on the other, to develop individuals who govern themselves as well as others.

This shaping of the self therefore takes the form of a confession as one of its specific technologies, where a specific relation of the self to the self emerges, in which the self analyses and governs itself and where the "freedom" of the academic acts as the starting point for governing and also as its effect. By inviting academics to converse with managers as "equals", and by providing an opportunity to reflect quite openly about work, work conditions and potentially private matters, the freedom of the academic becomes a prerequisite for this relationship. Individuals are positioned as free to choose whether they wish to participate in an interview, and through such choice they are constructed as "free".

\section{Logbooks}

Another area in which academics are involved, and where confession operates is in their relationship with students. Here, the focus is specifically on a currently popular teaching method used in academia, for example in medical studies (Denton et al., 2006; Fejes, 2008, 2011), teacher training (Korthagen, 1999; Hultman et.al., 2011) and engineering studies (Osgood, 2013). The general idea of the logbook is that students reflect on their progress during a certain course by making notes in a logbook. These thoughts may relate to learning 
goals, specific tasks, the learning process, or even their behaviour, capabilities and goals in life. At the same time, the logbook can act as a basis for assessment of student progress. If we look more closely at what the aim of the logbook is considered to be, in medical education it is seen in the following terms:

[L]ogbooks serves as a tool for program evaluation, leading to improvement and standardization of student's educational experience...logbook information can be used to reflect the process of education, including depth and breadth of a student's personal learning experience, ability and work habits. (Denton et al., 2006: 153-154)

Here, the idea is that the logbook is a tool for evaluation and assessment, for improving students' experiences, and as a way for students to document their learning and abilities. Similar notions of progress and development can be seen in relation to engineering education, where the guidelines state that for:

engineering educators who employ active learning techniques such as design projects, logbooks are an ideal way to enhance student's to communicate effectively...logbooks are primarily used in the engineering profession as a way to document an individual's progress with a particular project. (Osgood, 2013)

Here the aim of the logbook is more specific, as it is related to progress in a particular project and to an ability to communicate.

In relation to teacher training, the aim is broader, and is directed at developing generic skills such as an ability to reflect: "A logbook in which the student teachers record their own reflections on a particular lesson or meeting with the teacher educator ... the important thing is the question of how student teachers can learn to reflect better through the use of a logbook" (Korthagen, 1999: 195). Furthermore, the focus here becomes more directed at emotions and self-evaluation, where the student needs to ask her/himself, "How did I learn?" "How did I feel about this?" "Which problems and strong points do I see in my own way of learning?” (Korthagen, 1999: 196). In addition, “A prime aspect of learning from one's work as a teacher is the ability to step back and observe one's feelings of irritation, impatience and happiness, to take them seriously and to use them as an occasion for reflection" (Korthagen, 1999: 196). An example of such kind of reflection is provided by Hultman et.al., (2011: 129) in their studies of teacher students placement. One of their examples is an excerpt from a student logbook reads:

Many of these issues [that students should raise their hand, avoid repeating students answers, not to give corrections by asking questions] were my goal before the lessons of the day. I have become more attentive to my [faults]. I feel great frustration when I get aware that I still act incorrectly, despite trying to aware of these issues all the time.

Such statements further illustrate how the confession, and the logic of scrutinizing the self, is mobilised through the logbook. The logbook is thus related to questions of epistemology as well as ontology. On the one hand, the logbook is construed to be a tool for students to reflect on their specific actions in relation to a certain project or a particular way of working. Here the focus is on using the logbook as a way of improving professional action in practice. On the other hand, it encourages students to reflect on themselves, scrutinising their own ability 
to learn, their feelings about it, and what their strong and weak points are, as a basis for building a new and improved self. As the last quotation illustrates, ones actions and behaviour, is something one should always reflect about, and preferably disclose in the logbook. Here, there is a conflation of the private emotional capabilities of the student, the knowledge of professional practice and putting it into action.

Both technologies of power and the self are at play here. Firstly, students are positioned within a power relation where they are asked to scrutinise their actions in practice, as well as their capabilities, emotions and behaviour, and thus take responsibility for their own learning progress. In being asked to take notes on these aspects in the logbook, they are required to turn their gaze inwards, scrutinising themselves and relating themselves to norms of best practice, i.e. they are disclosing themselves in relation to a "virtual" other who is the one requiring and asking for the confession. Through the confession, a modification of the self is expected. This modification is not coerced, but rather elicited and fostered. The students reflect on their inner selves through their own freedom. The logbook is thus part of a wider discourse on governance, where the desirable norms produce subjects at the same time as the subjects produce the desirable norms. Writing the logbook is about writing the self, namely, about becoming a new and improved self. On the other hand, technologies of power operate when and if the logbook is made available to the teacher, and/or to their peers. In such cases, students are engaging in a public disclosure of themselves making their own judgements, assessment and knowledge about themselves visible for others to scrutinise, judge, assess and rank in relation to the norm.

These two intersecting ways in which power operates could be called objectification and subjectivation. On the one hand, the student is objectified through comparison and ranking, and thus normal and deviant behaviour, knowledge and capabilities are constructed and made visible. On the other hand, "the normal" is subjectivised through processes of self-scrutiny and working on themselves as individuals. The logbook therefore operates both as an objectifying and subjectivising technique in terms of shaping desirable student subjectivity. Through the conduct of conduct, academics as well as students are part in governing the self as well as others.

\section{Confessing academics and living the present otherwise}

In this article, I have argued that academics are enmeshed in complex power relations where technologies of power and the self intersect. Through examples of the appraisal interview and logbooks as governing techniques, I have illustrated how confession, as a technology of the self, operates both on and through academics themselves in terms of the conduct of conduct. The academic is not only invited to reflect on her or his performance, faults, temptations and desires in academia and in private life, but as a teacher, mobilises the same kind of technology in relation to students. These dynamics of power are connected to wider changes in society, where discourses on NPM have become all pervasive in terms of how to organise and govern public institutions. In NPM, focus is directed at accountability, explicit standards and measures of performance, output, rewards linked to performance, competition and so on. This all serves to mobilise a neoliberal notion of freedom, where freedom becomes both the starting point for and the effect of governing (cf. Rose, 1999). Through, e.g. the academics' choice to participate in the appraisal interview, in accordance with the norm, freedom is mobilised. At the same time, the academic, through the appraisal interview, is shaped as a free individual who takes responsibility for her or his own development as well as the development of the university. Similarly, through the mobilisation of the logbook the academic invites the students to use their freedom to reflect on their progress. At the same 
time, through writing the logbook, students are shaped as free, i.e. they have used their freedom.

However, simply by mobilising confessional techniques in relation to students, academics are governing themselves, as they are themselves engaged in this technology by others (e.g. their manager). Thus, it might seem as if the confession is a circular discourse and practice without escape. However, there are always points of resistance and ways of "living the present otherwise” (Foucault, 1979). As we can never exist outside power relations, we will always be products of power. However, we are not necessarily subjugated to the dominating discourses. If we were subjugated, subjectivity would be determined rather than elicited and fostered, and power would no longer be exercised as a result; power would then have been supplanted by a situation of constraint. Thus, freedom is a prerequisite for the exercise of power, and is found in the "agonism" (Foucault, 1983: 222) of power relations. People are always incited to act in a particular way, but may always wilfully act in disregard of this (Foucault, 1983; Nicoll and Fejes, 2008). To disregard this incitation, people can draw on marginalised discourses or those that lie outside of the true, i.e. in the "teratology of knowledge" where "there are monsters on the prowl ... whose forms alter with the history of knowledge" (Foucault, 1996: 348). It is therefore possible to draw on marginalised discourses, or "monsters", although the person who is speaking might then be positioned outside of the true. However, drawing on marginalised discourses can open up spaces for new propositions and new discourses to emerge, take hold and eventually become positioned within the true, presenting possibilities to live the present otherwise. Such work is partly done through genealogical analyses, and in the next section I will return to the ancient Greek practice of care of the self as one of many potential alternatives to current discourses on how the university and academics are being governed.

\section{Books of life}

The aim of Foucault's genealogy was to provide alternatives to the taken-for-granted-ness of the present by highlighting alternate ways of caring for the self, and other relations between care of the self and knowledge of the self. In the above outline of the emergence of confession, I referred to the Stoics' practice of writing diaries, which aimed to document the deeds of the day in such a way that good deeds left undone could be rectified in the following days. The goal of this task was to memorise truth as a starting point for action. By doing so, the Stoics could achieve self-mastery and turn life into an art of existence. The practice brought into congruence the gaze of the other (the true discourse) and the gaze directed towards oneself, in order to measure everyday actions in relation to the rules of life. With Christianity, writing became a way of rendering visible the most hidden impulses, in order to excavate guilt and break free from these impulses. In other words, writing became a test rather than a way of turning life into an art. However, Foucault (1994) also spoke of one other form of writing which was already well known during the first and second centuries: hupomnêmata.

Hupomnêmata were books in which a person took notes on events they had witnessed, as well as book extracts and ideas they had overheard. The book also allowed writers to further elaborate on ways of overcoming weaknesses or other obstacles in life. These books did not merely serve as memory aids. Instead, they provided a framework for action. Readers were encouraged to keep these books nearby, reread them and meditate on them while they were conversing with themselves and others. "It is a matter of constituting a logos bioethikos for oneself, an equipment of helpful discourses ... they must form part of ourselves ... the soul must make them not merely its own but itself” (Foucault, 1994: 210). The aim was not to 
reveal the hidden, as was the case with Christianity in a later era. Instead, it was to capture that which had already been, in order to shape the self. The books of life helped individuals to detach themselves from thoughts of the future to focus on thoughts of the past. Foucault notes, "Through the interplay of selected readings and assimilative writing, one should be able to form an identity through which a whole spiritual genealogy can be read" (Foucault, 1994: 214). Through the book, each entry was incorporated into a whole in the same way that a singer creates a choir by joining other singers. In this case, the individual voice becomes inseparable from the totality of the choir. In summary, the concept of the hupomnêmata "was a matter of constituting oneself as a subject of rational action through the appropriation, the unification, and the subjectivation of a fragmentary and selected already-said" (Foucault 1994: 221) in order to care for the self and to build life as an art. Hupomnêmata were concerned with existence rather than purity.

Although the practices of hupomnêmata involved surveillance of the self, either by a virtual or a "real" other, this surveillance was chosen by the authors themselves. These books were written out of a concern for the self and as a chosen practice of self-care for building life as an art. This practice differed from the modern practice of self-surveillance, as today "we first find ourselves monitored, without having chosen to be, and then we internalize this surveillance (Taylor, 2010: 198)". Thus, the concept of the hupomnêmata provides an alternative way of shaping the relation of the self to the self that is different from the modern forms of confession such as that which is mobilised through the governing techniques of the appraisal interview and the logbook.

Today, these techniques, as technologies of power and the self, position care of the self as something which should coincide with the norms of current discourses of academia. To care for the self is to take upon oneself the responsibility to provide that which is defined as "quality" in current discourses on NPM, not primarily in the name of the university, but rather in the name of the self. By producing "quality", the academic should produce what s/he desires, which coincides with the aspirations of the university. Such actions are not forced upon the academic, but rather elicited, fostered and invited by the "other", whether this may be the university manager, other academics, the student, or the academic her- or himself as represented through "the virtual other". Through the confession, the academic is invited to disclose knowledge of the self as a way of self care. In such a way, external monitoring is internalized by the academic (cf. Taylor, 2010) at the same time as the academic mobilises external monitoring in relation to his/her students, i.e. the conduct of conduct. To care for the self is thus to build a new and improved self which is both desired by the academic but which also coincides with the norms of good behaviour.

Books of life, on the other hand, provide one of many alternative ways to shape the relation of the self to the self as compared to the confession. These books were written out of a concern for the self (i.e. a will to care for the self). Self-care was aimed at preparing oneself for life, by taking notes on the already said rather than on the self. On the basis of these notes, the subject should act and shape life as an ethical enterprise of the self. By caring for the self, we come to know who we are. By writing the book of life, the self is shaped through a self-care process rather than something that needs to be deciphered, made visible and normalised. Selfmonitoring is chosen here instead of something coming from the outside. Books of life therefore draw on discourses other than the dominant ones in the present, thus constituting a different relation of the self to the self. The academic caring for the self would thus focus on seeking truth in what has been forgotten as a basis for action and in order to know the self. 
This would be done in contrast to the search for self-knowledge as a way to become a new and improved self in accordance with what the dominating discourses require.

\section{Ending notes}

By introducing books of life, as well as the wider genealogy of confession as elaborated based on the work of Michel Foucault, the aim of this article has been to provide one of many possible alternatives of how it might be possible, as an academic, to live the present otherwise. However, I do not provide any suggestions for how books of life should be used in academia as by doing so I would place myself in a position of truth-telling. Rather, the genealogy is provided to illustrate how there are other possibilities than the dominating ones to shape the relation of the self to the self, with a focus on self-care rather than on knowing, or to quote Rose (1999: 283), where "each person's life should be its own telos. It would thus have its own minimal normativity: we should oppose all that which stands in the way of life being its own telos." Here, the point of departure would be the self of the academic as an ethical subject of action rather than as a knowing subject (cf. Foucault, 2005; Simons and Masschelein, 2009). By choosing to let life be its own telos, and thus go against dominating discourses such as NPM, the academic engages in what Foucault (2008) called parrhesia, or dangerous truth-telling (cf. Zembylas and Fendler, 2007). Such act puts the academic at risk of being construed as abnormal, and in need of further correction. At the same time, however, the act provides a space for resistance which might open up possibilities to live the present otherwise (cf. Foucault, 1979). In this sense, one could say that I'm suggesting, that alternatives are a kind of way of "cutting...into how we live the present. Knowledge that cuts 'introduces a discontinuity', or works similar to a process of de-subjectivation...it opens up spaces for care for the self, 'to live the present otherwise'” (Simons and Masschelein, 2014: 92). Thus, it might be time for academics to ask other questions than those concerning the truth about the self.

The moment, maybe, is coming for us to ask: do we really need this hermeneutics of the self (which we have inherited from the first centuries of Christianity? Do we need a positive man who serves as the foundation of this hermeneutics of the self?) Maybe the problem of the self is not to discover what it is in its positivity; maybe the problem is not to discover a positive self of the positive foundation for the self. Maybe our problem now is to discover that the self is nothing else than the historical correlation of the technology built in our history. Maybe the problem is to change those technologies (or maybe to get rid of those technologies, and then, to get rid of the sacrifice which is linked to those technologies), And in this case, one of the main political problems nowadays would be, in the strict sense of the word, the politics of ourselves. Foucault (1997: 230-231),

\section{References}

Besley T and Peters M (2007) Subjectivity \& Truth: Foucault, Education and the Culture of the Self. New York: Peter Lang.

Breidenstein G and Thomson C (2015) Confession and subjectification in school performance evaluations. In: Fejes A and Nicoll K (eds) Foucault and a politics of confession in education. London: Routledge, pp. 21-34.

Deem M (2004) The knowledge worker, the manager-academic, and the contemporary UK university: New and old forms of public management? Financial accountability \& Management 20(2): 107-128. 
Dahlstedt M, Fejes A and Schönning, E (2011) The will to (de)liberate: Shaping governable citizens through cognitive behavioural programmes in school. Journal of Education Policy 26(3): 399-414.

Denton GD, DeMott C, Pangaro LN and Hemmer PA (2006) Narrative review: Use of student-generated logbooks in undergraduate medical education. Teaching and learning in medicine: An international journal 18(2): 153-164.

Fejes A (2008) Governing nursing through reflection: a discourse analysis of reflective practices. Journal of Advanced Nursing 64: 243-50.

Fejes A (2011) Confession, in-service training and reflective practices. British Educational Research Journal 37(5): 797-812.

Fejes A and Dahlstedt M (2014) The confessing society: Foucault, confession and practices of lifelong learning. London: Routledge.

Fejes A and Nicoll K (eds) (2015) Foucault and a politics of confession in education. London: Routledge.

Fejes A and Nicoll K (eds) (2008) Foucault and lifelong learning: Governing the subject, London: Routledge.

Fejes A and Nylander E (2014) The Anglophone International(e): A bibliometrical analysis of three adult education journals, 2005-2012. Adult Education Quarterly, 64(3): 222-239.

Foucault M (1979) Vivre autrement le temps. In: Defert D, Ewald F and Lagrange J (eds) Dits et écrits III 1976-1979. Paris: Gallimard, pp. 788-790.

Foucault M (1983) On the genealogy of ethics: an overview of work in progress. In: Dreyfus HL and Rabinow P (eds) Michel Foucault: Beyond Structuralism and Hermeneutics. Chicago: The University of Chicago Press, pp. 229-252.

Foucault M (1994) Self Writing. In: Rabinow P (ed) Ethics: Subjectivity and Truth. New York: New Press, pp. 207-22.

Foucault M (1996) The discourse on language. In: Kearney R and Rainwater M (eds) The Continental Philosophy Reader edited. London: Routledge, pp. 339-360.

Foucault M (1997) The politics of truth. Los Angelse: Semiotext(e).

Foucault M (1998) The Will to Knowledge: The History of Sexuality: 1. London: Penguin Books.

Foucault M (2003) Technologies of the self, In: Rabinow P and Rose N (eds) The Essential Foucault: Selections from the Essential Works of Foucault 1954-1984. New York: The New Press, pp. 145-169.

Foucault M (2005) The Hermeneutics of the Subject: Lectures at Collège de France 19811982. New York: Palgrave-Macmillan.

Foucault M (2007) Security, Territory, Population: Lectures at the Collège de France 19771978. Houndmills: Palgrave MacMillan.

Foucault M (2008) The Government of self and others: Lectures at the Collège de France 1982-1983. New York: Palgrave-MacMillan.

Hicks D (2012) Performance-based university research funding systems. Research Policy 41(2): 251-261.

Hodgson N (2015) Visualization, performance and the figure of the researcher. In: Fejes A and Nicoll K (eds) Foucault and a politics of confession in education. London: Routledge, pp. 77-90

Hultman G (2011) Samspelet lärarstuderande - handledare: Den verksamhetsförlagda utbildningen. Pedagogisk forskning i Sverige 16(2): 118-137.

Krejsler J (2007) Discursive strategies that individualize: CVs and appraisal interviews. International Journal of Qualitative Studies in Education 20(4): 473-490. 
Korthagen FAJ (2009) Linking reflection and technical competence: the logbook as an instrument in teacher education. European Journal of Teacher Education 22(2-3): 191207.

Larsson S (2010) Invisible colleges in the adult education research world. European Journal for Research on the Education and Learning of Research 1(1-2): 97-112.

Larsson S (2009a) An emerging economy of publications and citations. Nordisk Pedagogik 29(1): 34-52.

Larsson S (2009b) A pluralistic view of generalization in qualitative research. International Journal of Research \& Method in Education 32(1): 25-38.

Liedman SE (2013) Pseudo-quantities, new public management and human judgement. Confero: Essays on education, philosophy and politics 1(1): 45-66.

Malmö University (2014) Medarbetarsamtalet. Retreived 2014-0110. https://www.mah.se/upload/MEDARBETARE/Dokument/Medarbetaren\%20i\%20sam verkan-medarbetarsamtalet-13nov2012.pdf

Masschelein J, Simons M, Bröckling U and Pongratz L (2007) The learning society from the perspective of governmentality. Oxford: Blackwell publishing.

Ministry of Education (2007) Resurser för kvalitet. Stockholm: Ministry of Education.

Nicoll K (2015) Assessing confession in shaping the professional. In: Fejes A and Nicoll K (eds) Foucault and a politics of confession in education. London: Routledge, pp.

Nicoll K and Fejes A (2008) Mobilizing Foucault in studies of lifelong learning. In: Fejes A and Nicoll K (eds) Foucault and Lifelong Learning: Governing the Subject. London: Routledge, pp. 48-61.

Olson U, Petersson K and Krejlser JB (2015) On confessional dialogue and collective subjects. In: Fejes A and Nicoll K (eds) Foucault and a politics of confession in education. London: Routledge, pp. 93-105.

Osgood J (2013) Effective use of logbooks in engineering education: enhancing communication through short design activities. Teaching innovation projects $3(1)$, article 4.

Peters M, Besley T, Olssen M, Maurer S and Weber S (eds) (2009) Governmentality Studies in Education. Rotterdam: Sense Publishers.

Popkewitz T and Kirchgasler C (2015) Fabricating the teacher's soul in teacher education. In: Fejes A and Nicoll K (eds) Foucault and a politics of confession in education. London: Routledge, pp. 35-47.

Power M (1999) The audit society: Rituals of verification. Oxford: Oxford University Press.

Rose N (1989) Governing the Soul: The Shaping of the Private Self. London: Routledge.

Rose N (1991) Governing by numbers. Figuring our democracy. Accounting, Organizations and Society 16(7): 673-692.

Schimank U (2005) New public management and the academic profession: Reflections on the German situation. Minerva 43: 361-376.

Simons M and Masschelein J (2014) The truth that I say to you, well, you see it in myself: On research as education, as philosophy, as way of life. In: Reid AD, Hart MA and Peters M (eds) A companion to research in education edited. Dordrecht: Springer, pp. 83-96.

Simons M and Masschelein J (2009) The art of not being governed like that and at that cost: comments on self-study in studies of governmentality. In Peters M, Besley T, Olssen M, Maurer S and Weber S (eds) Governmentality Studies in Education. Rotterdam: Sense Publishers, pp. 527-548.

Taylor C (2010) The Culture of Confession from Augustine to Foucault: A Genealogy of the 'Confessing Animal'. London: Routledge. 
University of Gothenburg (2014) Utvecklingssamtal: Medarbetarens förberedelser. Retrieved 14-01-10. http://medarbetarportalen.gu.se/digitalAssets/1476/1476338_utvecklingssamtal--medarbetarens-f--rberedelser-gu-20140224.pdf

Zembylas $\mathrm{M}$ and Fendler L (2007) Reframing emotion in education through lenses of parrhesia and care of the self. Studies in Philosophy and Education 26(4): 319-333. 